\title{
Measuring the Main Factors that Impact Consumers Purchasing Intentions towards Shopping Online
}

\author{
Ms. Farah Badawi ${ }^{1}$, Dr. AymanMetwally ${ }^{2}$ and Dr. EimanNegm ${ }^{3}$
}

\author{
${ }^{1,2,3}$ Arab Academy of Science, Technology, and Maritime Transport \\ College for Management and Technology \\ Al Giza Desert, Giza Governorate, Egypt
}

\begin{abstract}
The purpose of this research is to measure the main factors that impact consumers purchasing intentions towards shopping fashion online. It also aims to understand the relationship between attitudes, subjective norms (adapted from the theory of reasoned action), traditional media, untraditional media (adapted from the cultivation theory), perceived usefulness, perceived ease of use, perceived enjoyment (adapted from the technology acceptance model) and online purchase intention. This study is a Quantitative research. This study is cross sectional. Data was collected just once during January and February 2021. This study is descriptive in purpose. The research aims to systematically describe the population understudy, and the phenomenon being studied (the variables that impact consumers purchase intention towards online shopping). This study focuses on youth and young adults. The research selected the sample using nonprobability sampling. The data collection tool was online administrated questionnaires. The questionnaires were placed on popular social media shopping groups so online shoppers can fill out. 405 questionnaires were analyzed. Based on the hypothesis testing, some of the hypotheses were supported, while other hypotheses were not supported. In this study, there is a relationship between attitude towards online shopping and purchase intention to shop online; there is a relationship between perceived ease of use towards online shopping and purchase intention to shop online; and there is a relationship between perceived enjoyment towards online shopping and purchase intention to shop online. This study demonstrated that media (traditional and non-traditional), subjective norms, and perceived usefulness towards
\end{abstract}

online shopping did not impact consumers' purchase intention to shop online.

Keywords: Attitude, Consumer Behavior, Hedonic Motives, Media Influence, Online shopping, Purchase Intention, Subjective Norms, Utilitarian Motives

\section{Introduction}

Online shopping has become increasingly popular phenomenon worldwide (Jibril et al., 2020). Consumers rely on the Internet to help and improve many aspects of life (Kolias et al., 2019). This includes shopping (Akhter, 2015). Consumers no longer have to waste time going out to different stores and standing on lines to purchase the products and services they desire. Now, they can simply go online and look up practically anything they could need or want (Vasic, Kilibarda and Kaurin, 2019). Online shopping is the act (or the whole process) of purchasing products or services over the Internet (Elsoud and Othman, 2017). According to (Grewal, Hulland, Kopalle and Karahanna, 2019), online shopping or marketing is the use of technology for better marketing performance.

B2C Global Economic Report (2019) illustrated that businesses and marketers spend billions of dollars to facilitate different target segments of online shoppers. According to Rahman et al. (2018), online shopping became a common practice among consumers as it is associated with many benefits; buying on the Internet provides lower transaction and search cost as compared to other types of shopping; online shopping allows consumers to buy faster; online shopping provides more alternatives; and online shopping allows consumers to order product and services with comparative lowest price. 
The Business-2-Consumer sales worldwide reached \$2.36 trillion in 2018 and are expected to excel drastically in the coming ten years. For example, Electronic Marketers expects retail e-commerce sales to increase to $\$ 4.058$ trillion in 2020 , making up $14.6 \%$ of total retail spending that year (eMarketer, 2019). According to the research conducted by the B2C Global Economic Report (2019), digital buyer penetration reached close to $50 \%$ of Internet users worldwide in 2018, the e-commerce industry is set to evolve and expand. Thus, studying and researching e-commerce dynamics is practically significant. Rahman et al. (2018) explained that marketers need to carefully analyze the consumers' attitude and behavior towards the online shopping. According to Svobodová and Rajchlová (2020), businesses need empirical evidences from the market in order to devise strategies to meet the demand of online shoppers and flourish the practice of online businesses. Further, Kumar (2019) explained that research is needed to study consumer behavior in the field of online shopping, seeing the consumer attitudes towards and behaviors towards online shopping. Various firsthand research insights are needed to understand the matter, making this topic academically important.

Due to the popularity of this phenomenon, the purpose of this research is to measure the main factors that impact consumers purchasing intentions towards shopping fashion online. This research will study the literature to theoretically identify the main theories that can explain the essential factors that are deemed significant in impacting consumer behavior towards online shopping.

\section{Literature Review}

Research illustrated that it is essential for organizations to realize consumer behavior as a key to success for both survival and profit generation in the modern economy with many products per competitor(Amir, Mannan and Nasiruddin, 2020).Assael (1995)explained the importance consumer behavior consideration:"Consumers determine the sales and profits of a firm by their purchasing decisions. As such, their motives and actions determine the economic viability of the firm" (p.3). Various theories have emerged to describe the factors that impact consumer behavior. The following paragraphs summarize several theories that shed insights on how consumers think and behavior towards online shopping.

\subsection{Theory: Hedonic and Utilitarian Values}

The consumer behavior theories propose that consumption behavior is determined by personal values. Values can be defined as "desirable transsituational goals, varying in importance, that serve
ISSN 2455-6378

as guiding principles in the life of a person or other social entity" (Schwartz, 1994, p. 21). Bowen et al. (2019) defined values related to purchasing goods and services as: "the outcome of a shopping experience" (p.126). Furthermore, the consumer behavior theories propose that two types of values exist when it comes to guiding consumption behavior: the utilitarian and hedonic values (Bowen et al., 2019).Utilitarian values reflect consumers' standards that are related to functional and nonsensory attributes. Utilitarian value is determined by using monetary savings and convenience concepts (Katt and Meixner, 2020). According to past studies, they stated that some consumers who have utilitarian aspects of shopping experience, focused on functional and task-related values. Nevertheless, research did show that the majority of the human behaviors are fundamentally pleasure-seeking in nature (Chaney et al., 2018). Therefore, the second values that is held among consumers and guide their consumption is hedonic values. Hedonic values refer to the gratification and sensory attributes (KaytazYiğit, 2020). These values reflect the crucial factors of consumer intentions towards their shopping behaviors (Yong and Shenghua, 2018).

\subsection{Theory: Reasoned Action (TRA)}

Theory of Reasoned Action (TRA) is one of the first models to explain human behavior byFishbein and Ajzenin 1967 (Monhanty, 2019). TRA stated that a person's intention to perform a behavior is the main predictor that whether they will actually perform the behavior. Intentions explains people's willingness and effort in exerting a certain action. They are considered an explanation for the motivational factors that influence behavior (Ajzen and Driver, 1992). TRA states that there are two determinants of intention towards behavior: attitude and subjective norms. The attitude is based on the expectations and beliefs about personal influences of outcomes resulting from the behavior (Kasten et al., 2019). The second determinant is subjective norm. This refers social influence thatpressure people to perform or not to perform the behavior (doekhie et al., 2020).

\subsection{Theory: Technology Acceptance Model (TAM)}

Based on Ajzen and Fishbein's (1980) TRA, the technology acceptance model (TAM) emerged(Taherdoost, 2018). The TAM is an information service theory that explains how users come to accept and use a specific technology (Hanjaya and Gunawan, 2019). TAM predicts individual's use of information technology (Athapaththu and Kulathunga, 2018). The TAM can provide a useful insight into user/internet interaction (Lai, 2017). According to the TAM, individual's attitude regarding the use of technology is influenced 
by two variables: ease of use of the technology and the perception of usefulness of the technology (Lai, 2017). The perception of usefulness of the technology refers to the individual's believe that the use of a specific technology will improve his or her job performance. Ease of use of the technology refers to the individual belief that the use of the technology is both physically and mentally free of effort (Mlekus, 2020).Further research regarding the emergence of technology have added an extra variable to the TAM, which is perceived enjoyment. Perceived enjoyment in the TAM explains that when consumers feel pleasure, they straightforwardly accept the usage of the new technology adoption. Perceived enjoyment affect consumers to use the new technology (Sudono, Adiwijaya and Siagian, 2020).

\subsection{Theory: Cultivation}

The study of traditional media and the new media originates its operational framework from the Cultivation theory. Cultivation is defined as: "a socio cultural theory regarding the role of television in shaping viewers' perceptions, beliefs, attitudes, and values" (Gerbner and Gross, 1976 p.3). The cultivation theory mass media, especially the television creates a shared way of seeing the world (Ladewig, 2020). Cultivation theory proposes that the whole value system made of ideologies, assumptions, beliefs, images and perceptions is mainly formulated by television. The television
ISSN 2455-6378

presents invisible and visible values, rules, and moral for what is right, what is significant, and what is suitable in a social conversation in a hidden manner (Mosharafa, 2015) .T segassem evititeper ehthat audiences receive became the foundation of their general worldview (Daniel, 2017). However, the common repetition of the content and forcing pictures shared on the television will penetrate and influence a person social values and subcultures (Zolotukhin, Zolotukhina, Sedina and Kozyreva, 2020).Cultivation studies on the effect of other media types, particularly in the digital or online context are gradually increasing. Today, since nontraditional media has become popular among audiences, they are beginning to cultivate this media content; as they are highly active participants of and contributors to the media (Kapoor et al., 2018). Audiences are shifted to be present on social media networking sites (SNS) to read and share content (Voramontri and Klieb, 2019).

Based on these theories, the research developed a proposed conceptual framework (figure 1) to be tested to identify the significant variables that influence consumers online shopping behaviors. According to the model, it is hypothesized that: (h1) attitude towards the behavior (h2) subjective norms (h3) traditional media (h4) non-traditional media (h5) ease of use (h6) usefulness (h7) enjoyment impact consumer purchase intention online.

\section{Figure 1: The proposed Conceptual Framework}

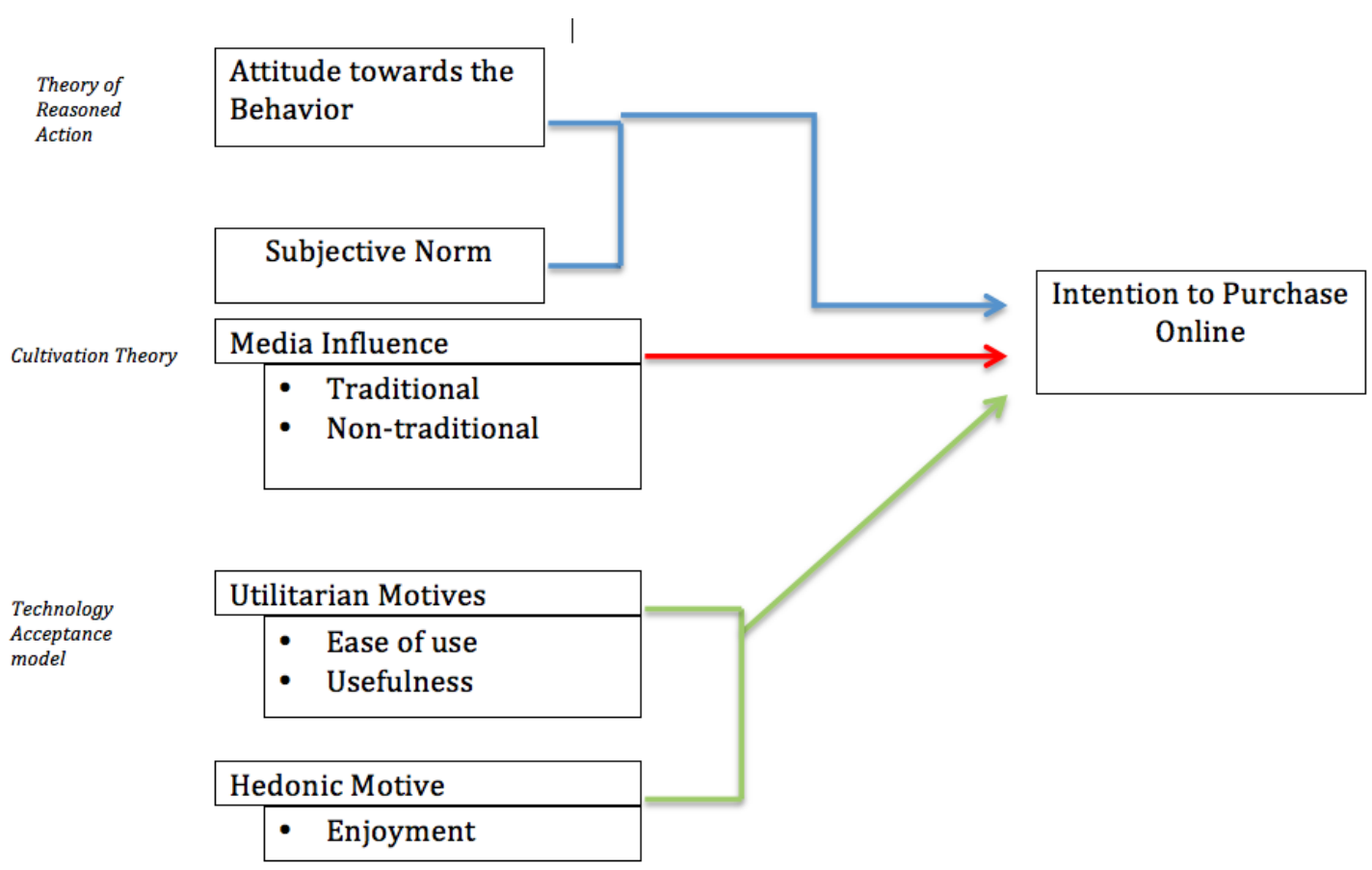




\section{Research Methodology}

This study is a Quantitative research. Willis (2007) identified quantitative approach as a way to ask people about their opinions in a structured way through surveying people in fairly large numbers and through making sure they are a representative sample of the target market. This study is cross sectional. Data was collected just once during January and February 2021. This study is descriptive in purpose. The research aims to systematically describe the population understudy, and the phenomenon being studied (the variables that impact consumers purchase intention towards online shopping). The unit of analysis is individuals. This study focuses on youth and young adults. According to the Eurostat (2021), those aged 25-54 had the highest share of online shoppers among Internet users up to 2018. In 2020, individuals aged 16-24 showed the biggest increase of online shopping globally (29 percentage points). The research selected the sample using nonprobability sampling. The data collection tool was online administrated questionnaires. The questionnaires were placed on popular social media shopping groups so online shoppers can fill out.

The questionnaire was made up of several scale measurements taken from prior studies and adjusted to fit this study. All the scales were likert scales. The scale attitude was taken from Taylor and Todd (1995) research. The scale subjective norms was taken from Huarng and Christopher (2003). The scale traditional media was taken from Chen et al. (2018). The scale non-traditional media was taken from Delceaand Cotfas (2019). The scale ease of use was taken from Zhy et al. (2011). The scale usefulness was taken from Ranganathan and
ISSN 2455-6378

Ganapathy (2002). The scale enjoyment was taken fromVenkatesh et al. (2012). The scale purchase intention was taken from Venkatesh et al. (2012). Table 1 illustrates theCronbach alpha for the scales when tested in prior studies.

The questionnaire contained two versions - English and Arabic language. Face validity was conducted to confirm the adequacy of the questionnaire. Practitioners and Academics reviewed the statements found in each scale to check and approve that it is vibrant enough to measure the intended variable as well as it simple and makes sense. It's similar to content validity, but face validity is a more informal and subjective assessment. In addition, a pilot test was conducted before the actual data collection took place. A pilot testing is a rehearsal of the research data collection tool effectiveness, allowing the research to test the questionnaire on a small number of participants. In this study, the pilot test included 50 respondents. The pilot test verified the questionnaire adequately collect the needed information.

Once the actual data collection was completed, the reliability analysis is conducted in this study in order to make sure that the collected data is of value because the scales consistently reflect the construct it is measuring. Cronbach's alpha is the most common measure of internal consistency ("reliability"). Next, the validity analysis was conducted to determine the accuracy of the measure (whether the results really do represent what they are supposed to measure). According to the analysis (as shown in table 1), all scales are reliable and valid as the Cronbach's alpha and validity ranged from 0.604 to 0.958 .

Table One: Reliability and Validity Analysis

\begin{tabular}{|l|c|c|c|}
\hline \multicolumn{1}{|c|}{ Variables } & $\begin{array}{c}\text { Prior Study Cronbach's Alpha } \\
(\mathbf{a})\end{array}$ & $\begin{array}{c}\text { Current study } \\
\text { Reliability }\end{array}$ & $\begin{array}{c}\text { Current study } \\
\text { Validity }\end{array}$ \\
\hline Attitude & 0.85 & 0.766 & 0.88 \\
\hline Subjective Norms & 0.864 & 0.898 & 0.95 \\
\hline Traditional Media & 0.89 & 0.958 & 0.98 \\
\hline Non-traditional Media & 0.89 & 0.950 & 0.97 \\
\hline Ease of Use & 0.917 & 0.704 & 0.84 \\
\hline Usefulness & 0.843 & 0.604 & 0.78 \\
\hline Enjoyment & 0.962 & 0.929 & 0.96 \\
\hline Purchase Intention & 0.91 & 0.894 & 0.95 \\
\hline
\end{tabular}

\section{Research Findings}

Out of 500 questionnaires distributed, 95 were eliminated due to the questionnaire incompletion or the eligible criterion of respondents. As a result, only
405 questionnaires were usable and analyzed. This study had $81 \%$ response rate. The respondents' background of this study is shown in table 2 . 
www.ijasrm.com

ISSN 2455-6378

Table Two: The Respondents Background

\begin{tabular}{|c|c|c|c|c|c|}
\hline Question & Number & Percentage & Question & Number & Percentage \\
\hline 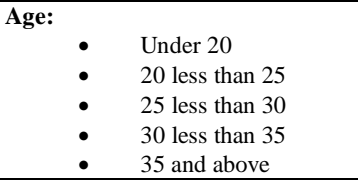 & $\begin{array}{l}124 \\
116 \\
94 \\
37 \\
34\end{array}$ & $\begin{array}{l}30.6 \\
28.6 \\
23.2 \\
9.1 \\
8.4\end{array}$ & $\begin{aligned} \text { Education: } & \\
\bullet & \text { High School } \\
\bullet & \text { College Degree } \\
\bullet & \text { Other }\end{aligned}$ & $\begin{array}{l}146 \\
202 \\
57\end{array}$ & $\begin{array}{l}36 \\
49.9 \\
14.1\end{array}$ \\
\hline $\begin{aligned} \text { Gender: } & \\
\bullet & \text { Male } \\
\bullet & \text { Female }\end{aligned}$ & $\begin{array}{l}143 \\
262\end{array}$ & $\begin{array}{l}35.3 \\
64.7\end{array}$ & $\begin{array}{cl}\text { City of Residence: } \\
\bullet & \text { Cairo } \\
\bullet & \text { Alex } \\
\bullet & \text { Other } \\
\end{array}$ & $\begin{array}{l}40 \\
340 \\
25\end{array}$ & $\begin{array}{l}9.9 \\
84 \\
6.2 \\
\end{array}$ \\
\hline $\begin{array}{cl}\text { Marital } & \text { Status: } \\
\bullet & \text { Single } \\
\bullet & \text { Married } \\
\bullet & \text { Separated/ Divorced } \\
\bullet & \text { Widowed } \\
\end{array}$ & $\begin{array}{l}318 \\
75 \\
11 \\
1\end{array}$ & $\begin{array}{l}78.5 \\
18.5 \\
2.7 \\
.2\end{array}$ & $\begin{array}{cl}\text { Number of Children: } \\
\bullet \quad \text { None } \\
\bullet \quad \text { One Child } \\
\bullet \quad \text { Two Children } \\
\bullet \quad \text { More than Two Children } \\
\end{array}$ & $\begin{array}{l}335 \\
38 \\
24 \\
8\end{array}$ & $\begin{array}{l}82.7 \\
9.4 \\
5.9 \\
2.0\end{array}$ \\
\hline $\begin{array}{l}\text { Average monthly Income: } \\
\text { - } \quad \text { less than } 2,000 \\
\text { - } \quad 2,000 \text { less than } 5,000 \\
\text { - } \quad \text { Over } 10,000 \text { less than } 10,000 \\
\end{array}$ & $\begin{array}{l}22 \\
85 \\
63 \\
235\end{array}$ & $\begin{array}{l}5.4 \\
21 \\
15.6 \\
58.0\end{array}$ & $\begin{aligned} & \text { Occupation: } \\
& \text { - } \text { Manager/Executives } \\
& \text { - } \text { Clerks } \\
& \text { - } \text { Professionals } \\
& \text { - } \text { Academics } \\
& \text { - } \text { Self employed } \\
& \text { - } \text { Othents }\end{aligned}$ & $\begin{array}{l}34 \\
2 \\
20 \\
79 \\
30 \\
204 \\
36\end{array}$ & $\begin{array}{l}8.4 \\
.5 \\
4.9 \\
19.5 \\
7.4 \\
50.4 \\
8.9\end{array}$ \\
\hline
\end{tabular}

In this research, different analyses' were conducted: the reliability, validity, frequency, correlation and multiple regression. The Reliability analysis confirmed the dependability of scale used to measure the variables. The frequency analyses are conducted for the demographic variables to present the sample profile and to observe the respondents' outcome regarding the introduction questions related to online shopping. The Correlation analyses identified the strength, direction and significance of the variables in the hypotheses. The Multiple Regression analyses tested the hypotheses in this study.
Correlation analysis is the next test to be conducted. It is a statistical method used to evaluate the strength of relationship between two quantitative variables. A high correlation means that the variables have a strong relationship with each other, while a weak correlation means that the variables are hardly related. Table three illustrates the correlation analysis. Based on the analysis, all the relations found in the hypotheses are positively correlated, but with different strength.

Table Three: Pearson Correlation Analysis

\begin{tabular}{|c|c|c|}
\hline Hypothesis & Alpha (a) & Relation Description \\
\hline $\begin{array}{l}\text { There is a relationship between attitude towards online shopping and purchase } \\
\text { intention to shop online }\end{array}$ & $0.764 * *$ & $\begin{array}{l}\text { Relationship Significance: significant } \\
\text { Relationship Strength: strong } \\
\text { Relationship Direction: positive }\end{array}$ \\
\hline $\begin{array}{l}\text { There is a relationship between Subjective Norms and purchase intention to shop } \\
\text { online }\end{array}$ & $0.211 * *$ & $\begin{array}{l}\text { Relationship Significance: significant } \\
\text { Relationship Strength: weak } \\
\text { Relationship Direction: positive }\end{array}$ \\
\hline There is a relationship between traditional media and purchase intention to shop online & $0.270^{* *}$ & $\begin{array}{l}\text { Relationship Significance: significant } \\
\text { Relationship Strength: weak } \\
\text { Relationship Direction: positive }\end{array}$ \\
\hline $\begin{array}{l}\text { There is a relationship between non-traditional media and purchase intention to shop } \\
\text { online }\end{array}$ & $0.468 * *$ & $\begin{array}{l}\text { Relationship Significance: significant } \\
\text { Relationship Strength: medium } \\
\text { Relationship Direction: positive }\end{array}$ \\
\hline $\begin{array}{l}\text { There is a relationship between perceived usefulness and purchase intention to shop } \\
\text { online }\end{array}$ & 0.046 & $\begin{array}{l}\text { Relationship Significance: not significant } \\
\text { Relationship Strength: weak } \\
\text { Relationship Direction: positive }\end{array}$ \\
\hline $\begin{array}{l}\text { There is a relationship between perceived ease of use and purchase intention to shop } \\
\text { online }\end{array}$ & $0.532 * *$ & $\begin{array}{l}\text { Relationship Significance: significant } \\
\text { Relationship Strength: strong } \\
\text { Relationship Direction: positive }\end{array}$ \\
\hline $\begin{array}{l}\text { There is a relationship between perceived enjoyment and purchase intention to shop } \\
\text { online }\end{array}$ & $0.597 * *$ & $\begin{array}{l}\text { Relationship Significance: significant } \\
\text { Relationship Strength: strong } \\
\text { Relationship Direction: positive }\end{array}$ \\
\hline
\end{tabular}


Multiple regression is an extension of simple linear regression. It is a more sophisticated assessment of the hypotheses. In this study, the multiple regression is used to test the hypotheses. Multiple regression also allows the research to determine the overall fit (variance explained) of the model and the relative contribution of each of the predictors to the total variance explained.

Analysis of Variance (ANOVA) in the multiple regression consist of calculations that provide information about levels of variability within a regression model and form a basis for tests of significance. It checks if the model is significant overall in its development. Based on the analysis, the
ISSN 2455-6378

model used in this study was significant, with $A N O V A=0.000$. The adjusted R-squared is a modified version of R-squared that has been adjusted for the number of predictors in the model. According to the analysis, the adjusted $\mathrm{R} 2$ is 0.640 . This means that the independent variable in this study contributes $64 \%$ of the creation of the dependent variable. Finally, the sig value is used to test the hypotheses. In order for a hypothesis to be supported, the sig value should be lower than 0.05 ( $p<0.05)$. If the sig vale is higher, the hypotheses is deemed insignificant and not supported. Table 4 illustrates the outcome of the hypothesis testing.

Table Four: Hypothesis Testing

\begin{tabular}{|c|c|c|}
\hline Hypothesis & Sig Value & Hypothesis Testing \\
\hline $\begin{array}{l}\text { There is a relationship between attitude towards online shopping and } \\
\text { purchase intention to shop online }\end{array}$ & .000 & $\begin{array}{l}\text { Hypothesis Supported } \\
\text { Sig Value }=.000 \\
(\mathrm{p}<0.05) .\end{array}$ \\
\hline $\begin{array}{l}\text { There is a relationship between Subjective Norms and purchase } \\
\text { intention to shop online }\end{array}$ & .115 & $\begin{array}{l}\text { Hypothesis Not Supported } \\
\text { Sig Value }=.115 \\
\quad(\mathrm{p}>0.05) .\end{array}$ \\
\hline $\begin{array}{l}\text { There is a relationship between traditional media and purchase } \\
\text { intention to shop online }\end{array}$ & .258 & $\begin{array}{c}\text { Hypothesis Not Supported } \\
\text { Sig Value }=.258 \\
(\mathrm{p}>0.05) .\end{array}$ \\
\hline $\begin{array}{l}\text { There is a relationship between non-traditional media and purchase } \\
\text { intention to shop online }\end{array}$ & .887 & $\begin{array}{l}\text { Hypothesis Not Supported } \\
\text { Sig Value }=.887 \\
\text { ( } p>0.05) .\end{array}$ \\
\hline $\begin{array}{l}\text { There is a relationship between perceived usefulness and purchase } \\
\text { intention to shop online }\end{array}$ & .918 & $\begin{array}{c}\text { Hypothesis Not Supported } \\
\text { Sig Value }=.918 \\
(\mathrm{p}>0.05) .\end{array}$ \\
\hline $\begin{array}{l}\text { There is a relationship between perceived ease of use and purchase } \\
\text { intention to shop online }\end{array}$ & .004 & $\begin{array}{c}\text { Hypothesis Supported } \\
\text { Sig Value }=.004 \\
(\mathrm{p}<0.05) .\end{array}$ \\
\hline $\begin{array}{l}\text { There is a relationship between perceived enjoyment and purchase } \\
\text { intention to shop online }\end{array}$ & .000 & $\begin{array}{l}\text { Hypothesis Supported } \\
\text { Sig Value }=.000 \\
\quad(\mathrm{p}<0.05)\end{array}$ \\
\hline
\end{tabular}

\section{Research Discussion: Comparison with previous studies}

Based on the hypothesis testing, some of the hypotheses were supported, while other hypotheses were not supported. Therefore, when it comes to online shopping, some of the theories contained variations. The following paragraphs illustrate the research outcomes and how it was supported or opposed by prior studies.
Hypothesis One: There is a relationship between attitude towards online shopping and purchase intention to shop online. In this study, this hypothesis is supported. This outcome is similar to prior studies. For example, Hasbullah et al (2016) showed that the higher the attitude towards shopping online, the more frequent they will think of doing it. Law et al (2016) confirmed that people who have intentions to shop online hold positive attitudes towards digitalization. Shaouf et al (2018) justified that a positive attitude towards buying on the Internet influences positively the consumer's intention to use the Internet to shop. 
Hypothesis Two: There is a relationship between Subjective Norms and purchase intention to shop online. In this study, this hypothesis is not supported. This outcome contradicts prior studies. For example,Lim (2015) proposed that subjective norm does not significantly impact on the actual purchase through the internet but have a great important effect on online purchase intention. He et al. (2008) proved that the recommendations by third parties which is known as the subjective norm affected the purchase intention of the consumers. There is a consensus that subjective norm does has a positive significant influence on purchase intention towards online shopping (Leeraphong\&Mardjo, 2013; Jamil \& Mat, 2011).

\section{Hypothesis Three and Four: There is a relationship} between traditional media and purchase intention to shop online; there is a relationship between non-traditional media and purchase intention to shop online.In this study, these hypotheses are not supported. This outcome contradicts prior studies. For example,Tamoude (2020) indicated that if individuals are exposed to media daily, the media would shapes their purchasing decisions. Other studies explained that continuous exposure to media change consumers opinions and values over time, influencing their beliefs, attitudes, values and behaviors (Lita and Cho, 2013). Athapaththu and Kulathunga (2018) stated that when consumers intend to purchase a product and or service, they are affected directly by the various types of media.

Hypothesis Five:There is a relationship between perceived usefulness and purchase intention to shop online. In this study, this hypothesis is not supported. This outcome contradicts prior studies. For example, many prior studies (Hanjaya et.al, 2019, Ling, Daud, Piew, Keoy, and Hassan, 2011; Heijden, Verhagen and Creemers, 2003; Gefen et al., 2003) developed empirical evidence, showing perceived usefulness has an effect on purchase intention in performing the shopping online. Percieved usefulness was validated in the TAM in various contexts, specially in the online setting (Athapaththu and Kulathunga, 2018).

Hypothesis Six: There is a relationship between perceived ease of use and purchase intention to shop online. In this study, this hypothesis is supported. This outcome is similar to prior studies. For example, Alalwanet. al (2018) proved the influence of perceived ease of use on the customer intention to use a new technology. This influence is also supported by many studies which suggest that ease of use has a clear effect on purchase intention in doing online shopping (Ling, Daud, Piew, Keoy, and Hassan, 2011; Heijden, Verhagen and Creemers,

\section{ISSN 2455-6378}

2003; Gefen et al., 2003, Hanjaya et.al, 2019). It was added that the ease of use of the technology while performing the online shopping process is essential in forecasting the potential e- shopper's intention (shim et al., 2021). The TAM Model proved that perceived ease of use is an essential element that affects directly behavioral intention to shop online (Ali et. al, 2014).

Hypothesis eight: There is a relationship between perceived enjoyment and purchase intention to shop online. In this study, this hypothesis is supported. This outcome is similar to prior studies. For example, Alalwan et al. (2018) illustrated the perceived enjoyment has an essential role in affecting the customer intention to shop online. Research clarified and added that the higher the level of customers' feeling of enjoyment when they use the new technology, the higher their readiness to adopt it (shim et al., 2021). Ali, et al (2014) added that in the TAM Model Adoption, it was proved that perceived enjoyment, which is considered an important variable of the three elements in TAM model have a relationship with behavioral intention to shop online.

\subsection{Research Conclusion}

The purpose of this research is to measure the main factors that impact consumers purchasing intentions towards shopping fashion online. It also aims to understand the relationship between attitudes, subjective norms (adapted from the theory of reasoned action), traditional media, untraditional media (adapted from the cultivation theory), perceived usefulness, perceived ease of use, perceived enjoyment (adapted from the technology acceptance model) and online purchase intention. Therefore, this research will study the literature to theoretically identify a base for measuring the relationship of attitudes, subjective norms, traditional media, untraditional media, perceived usefulness, perceived ease of use, perceived enjoyment and online purchase intention in Egypt and consequently, test and verify empirically the relationship between the previously mentioned independent variables with purchase intention.

Based on the hypothesis testing, some of the hypotheses were supported, while other hypotheses were not supported. In this study, there is a relationship between attitude towards online shopping and purchase intention to shop online; there is a relationship between perceived ease of use towards online shopping and purchase intention to shop online; and there is a relationship between perceived enjoyment towards online shopping and purchase intention to shop online. This study demonstrated that media (traditional and non- 
traditional) does not influence consumers purchase intention to shop online. This study also showed that there is no relationship between subjective norms and purchase intention to shop online. This study demonstrated that there is a relationship between perceived usefulness towards online shopping and purchase intention to shop online. Based on the hypothesis testing, the proposed research model was adjusted to represent the empirical findings. Figure 2 illustrates the conclusion of this research.

Figure 2: Adjusted Research Model

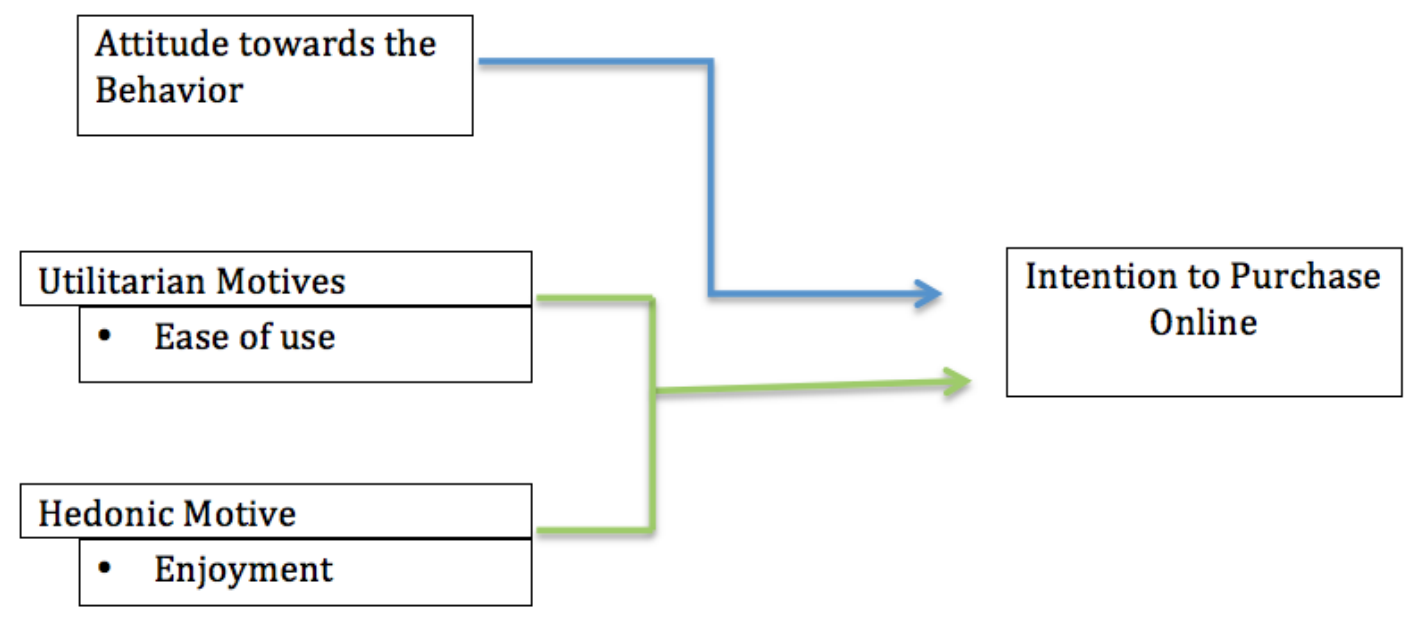

\subsection{Research limitation and Direction for future Studies}

Like any research, this research faced several limitations. For example, when it come to the model development, this study focused on the TRA, TAM, cultivation theory, and the hedonic and utilitarian values. This study did not take into consideration other theories that further explain consumer behavior. Therefore, it is recommended that future studies review other theories that can contribute to understanding consumer behavior towards online shopping. This study focus on a few values related to hedonic and utilitarian values. Future studies could assess other values related to consumers shopping online. When it came to the conduction of the data collection, this study used quantitative approach only; focused on one age group of consumers; focused on Egypt; used non-probability sampling; and was cross sectional in data collection. It is recommended that future studies use mixed research approach, especially the conduction of qualitative research approach in order to gather in-depth insights and collect rich insights from the consumers to understand their concepts, opinions, and experiences of online shopping to generate new ideas for research. It is recommended that future studies assess this topic among different age groups of online shoppers. It is recommended that future studies to test the conceptual framework on different nations, or to do a comparison study between the western nations and the Arab nations. It is recommended that future studies test the model on different online purchases, such as clothing, electronics, or home furnishing. It is recommended that future studies use probability sampling when a sampling frame is established. It is recommended that future studies use longitudinal study to see the before and after opinions of consumers when using online shopping.

\section{References}

[1] Ajzen, I., \&Fishbein, M. (1980).Understanding attitudes and predicting social behavior. Englewood Cliffs, NJ: Prentice-Hall.

[2] Alalwan A. A., Dwivedi Y. K., Rana N. P., Algharabat R. (2018). Examining factors influencing jordanian customers' intentions and adoption of internet banking: extending UTAUT2 with risk.J. Retail. Consum. Ser.40 125-138.

[3] Ali M, et al. (2014) Stress-dependent proteolytic processing of the actin assembly protein Lsb1 modulates a yeast prion. J BiolChem 289(40):27625-39

[4] Amir, R., Mannan, M. and Nasiruddin, M., 2020. Influence of corporate social responsibility on bottom of the pyramid consumers' purchase intention. International 
Journal of Business Innovation and Research, 21(2), p.259.

[5] Arjun Kumar, S., 2019. Recent Advances in Shopping Through Mobile: An Indian Perspective. SSRN Electronic Journal,.

[6] Assael, H. Consumer Behavior and Marketing Action, (5 Ed.) South-Western Collage Publishing, 1995.

[7] Athapaththu, J. and Kulathunga, D., 2018. Factors Affecting Online Purchase Intention: Effects of Technology and Social Commerce. International Business Research, 11(10), p.111.

[8] Bowen, G., Cai, Z., Fiorella, R. and Putman, A., 2019. Isotopes in the Water Cycle: Regional- to Global-Scale Patterns and Applications. Annual Review of Earth and Planetary Sciences, 47(1), pp.453-479.

[9] Chen, C., Xu, M., Anantaprakorn, Y., Rosing, M., Stanewsky, R. (2018). nocte Is Required for Integrating Light and Temperature Inputs in Circadian Clock Neurons of Drosophila.

[10]ConstantinosKolias, WeizhiMeng, GeorgiosKambourakis, Jiageng Chen, "Security, Privacy, and Trust on Internet of Things", Wireless Communications and Mobile Computing, vol. 2019, Article ID 6452157, 3 pages, 2019.

[11]Damien Chaney, Renaud Lunardo, RémiMencarelli. Consumption experience: past, present andfuture. Qualitative Market Research: An International Journal, Emerald, 2018, 21 (4), pp.402-420.

[12] Delcea, C. and Cotfas, L., 2019. Increasing awareness in classroom evacuation situations using agent-based modeling. Physica A: Statistical Mechanics and its Applications, 523, pp.1400-1418.

[13]Doekhie, K.D., Buljac-Samardzic, M., Strating, M.M.H. et al. Elderly patients' decision-making embedded in the social context: a mixed-method analysis of subjective norms and social support. BMC Geriatr20, 53 (2020).

[14]Ec.europa.eu. 2021. Online shopping ever more popular in 2020. [online] Available at: $<$ https://ec.europa.eu/eurostat/web/products -eurostat-news/-/ddn-20210217-1> [Accessed 26 May 2021].

[15] Gefen, D., Karahanna, E., \& Straub, D.W. (2003). Trust and TAM in Online Shopping:An Integrated Model. Management Information System, 27(1), 51-90

[16] Gerbner, G. and Gross, L., 1976. Living with Television: The Violence Profile. Journal of Communication, 26(2), pp.172199.

\section{ISSN 2455-6378}

[17] Grewal, D., Hulland, J., Kopalle, P. and Karahanna, E., 2019. The future of technology and marketing: a multidisciplinary perspective. Journal of the Academy of Marketing Science, 48(1), pp.1-8.

[18] Hanjaya, S., Kenny, S. and Gunawan, S., 2019. Understanding Factors influencing Consumers Online Purchase intention Via Mobile App: Perceived Ease of use, Perceived Usefulness, System Quality, information Quality, and Service Quality. Marketing of Scientific and Research Organizations, 32(2), pp.175-205.

[19] Hasbullah, N., Osman, A., Abdullah, S., Salahuddin, S., Ramlee, N. and Soha, H., 2016. The Relationship of Attitude, Subjective Norm and Website Usability on Consumer Intention to Purchase Online: An Evidence of Malaysian Youth. Procedia Economics and Finance, 35, pp.493-502.

[20] He W, et al. (2008) Rad9 plays an important role in DNA mismatch repair through physical interaction with MLH1. Nucleic Acids Res 36(20):6406-17

[21] Heijden, H.V., Verhagen, T., \&Creemers, M. (2003). Understanding online purchase intentions: Contributions from technology and trust perspectives. European Journal of Information System, 12, 41-48. Understanding Factors influencing Consumers Online Purchase intention Via Mobile App: Perceived Ease of use, Perceived Usefulness, System Quality, information Quality, and Service Quality.

[22]Huarng, A. and Christopher, D., 2003. Planning an effective Internet retail store. Marketing Intelligence \& Planning, 21(4), pp.230-238.

[23] Insider Intelligence. 2021. Ecommerce Continues Strong Gains Amid Global Economic Uncertainty. [online] Available at:

<https://www.emarketer.com/content/ecom merce-continues-strong-gains-amid-globaleconomic-uncertainty> [Accessed 26 May 2021].

[24] Insider Intelligence. 2021. Global Ecommerce 2019. [online] Available at: $<$ https://www.emarketer.com/content/global -ecommerce-2019> [Accessed 26 May 2021].

[25] J Furman Daniel, III, Paul Musgrave, Synthetic Experiences: How Popular Culture Matters for Images of International Relations, International Studies Quarterly, Volume 61, Issue 3, September 2017, Pages 503-516, 
[26] Jamil, N. A., Mat, N. K., 2011. To Investigate The Drivers of Online Purchasing Behavioral In Malaysia Based on the Theory of Planned Behavior (TPB): A Structural Equation Modeling (SEM) Approach. International CoferenceOn Management, (pp. 453-460)

[27] Jibril, A. B., Kwarteng, M. A., Pilik, M., Botha, E., \&Osakwe, C. N. (2020). Towards understanding the initial adoption of online retail stores in a low internet penetration context: An exploratory work in Ghana. Sustainability, 12(3), 854.

[28] Kapoor, K.K., Tamilmani, K., Rana, N.P. et al. Advances in Social Media Research: Past, Present and Future. InfSyst Front20, 531-558 (2018).

[29] Kasten, S., van Osch, L., Candel, M. et al. The influence of pre-motivational factors on behavior via motivational factors: a test of

\section{ISSN 2455-6378}

the I-Change model. BMC Psychol7, 7 (2019).

[30] Katt, F. and Meixner, O., 2020. Food waste prevention behavior in the context of hedonic and utilitarian shopping value. Journal of Cleaner Production, 273, p. 122878 .

[31] KaytazYiğit, M., 2020. Consumer mindfulness and impulse buying behavior: testing moderator effects of hedonic shopping value and mood. Innovative Marketing, 16(4), pp.24-36.

[32] Ladewig, J., 2020. Murder and Presidential Elections: A Cultivation - Based Issue Ownership Theory of Local Television News and Its Geographic Structure. Presidential Studies Quarterly, 50(4), pp.811-844. 